\title{
Estimates of the organic aerosol volatility in a boreal forest using two independent methods
}

\author{
Juan Hong ${ }^{1}$, Mikko Äijälä ${ }^{1}$, Silja A. K. Häme ${ }^{1}$, Liqing Hao ${ }^{2}$, Jonathan Duplissy ${ }^{1,3}$, Liine M. Heikkinen ${ }^{1}$, Wei Nie ${ }^{4}$, \\ Jyri Mikkilä ${ }^{1}$, Markku Kulmala ${ }^{1}$, Nønne L. Prisle ${ }^{5,1}$, Annele Virtanen ${ }^{2}$, Mikael Ehn ${ }^{1}$, Pauli Paasonen ${ }^{1}$, \\ Douglas R. Worsnop $^{6}$, Ilona Riipinen ${ }^{7}$, Tuukka Petäjä ${ }^{1}$, and Veli-Matti Kerminen ${ }^{1}$ \\ ${ }^{1}$ Department of Physics, University of Helsinki, P.O. Box 64, 00014 Helsinki, Finland \\ ${ }^{2}$ Department of Applied Physics, University of Eastern Finland, Kuopio 70211, Finland \\ ${ }^{3}$ Helsinki Institute of Physics, University of Helsinki, P.O. Box 64, 00014 Helsinki, Finland \\ ${ }^{4}$ Institute for Climate and Global Change Research \& School of Atmospheric Sciences, Nanjing University, \\ Nanjing, 210093, China \\ ${ }^{5}$ University of Oulu, Nano and Molecular Systems Research Unit, P.O. Box 3000, 90014 University of Oulu, \\ Oulu, Finland \\ ${ }^{6}$ Aerodyne Research, Inc., Billerica, Massachusetts, USA \\ ${ }^{7}$ Department of Environmental Science and Analytical Chemistry, Stockholm University, \\ 10961 Stockholm, Sweden
}

Correspondence to: Juan Hong (juan.hong@helsinki.fi)

Received: 28 August 2016 - Discussion started: 14 October 2016

Revised: 15 February 2017 - Accepted: 8 March 2017 - Published: 31 March 2017

\begin{abstract}
The volatility distribution of secondary organic aerosols that formed and had undergone aging - i.e., the particle mass fractions of semi-volatile, low-volatility and extremely low volatility organic compounds in the particle phase - was characterized in a boreal forest environment of Hyytiälä, southern Finland. This was done by interpreting field measurements using a volatility tandem differential mobility analyzer (VTDMA) with a kinetic evaporation model. The field measurements were performed during April and May 2014. On average, $40 \%$ of the organics in particles were semi-volatile, $34 \%$ were low-volatility organics and $26 \%$ were extremely low volatility organics. The model was, however, very sensitive to the vaporization enthalpies assumed for the organics $\left(\Delta H_{\mathrm{VAP}}\right)$. The best agreement between the observed and modeled temperature dependence of the evaporation was obtained when effective vaporization enthalpy values of $80 \mathrm{~kJ} \mathrm{~mol}^{-1}$ were assumed. There are several potential reasons for the low effective enthalpy value, including molecular decomposition or dissociation that might occur in the particle phase upon heating, mixture effects and compound-dependent uncertainties in the mass accommodation coefficient. In addition to the
\end{abstract}

VTDMA-based analysis, semi-volatile and low-volatility organic mass fractions were independently determined by applying positive matrix factorization (PMF) to high-resolution aerosol mass spectrometer (HR-AMS) data. The factor separation was based on the oxygenation levels of organics, specifically the relative abundance of mass ions at $\mathrm{m} / \mathrm{z} 43$ $(f 43)$ and $m / z 44(f 44)$. The mass fractions of these two organic groups were compared against the VTDMA-based results. In general, the best agreement between the VTDMA results and the PMF-derived mass fractions of organics was obtained when $\Delta H_{\mathrm{VAP}}=80 \mathrm{~kJ} \mathrm{~mol}^{-1}$ was set for all organic groups in the model, with a linear correlation coefficient of around 0.4 . However, this still indicates that only about $16 \%$ $\left(R^{2}\right)$ of the variation can be explained by the linear regression between the results from these two methods. The prospect of determining of extremely low volatility organic aerosols (ELVOAs) from AMS data using the PMF analysis should be assessed in future studies. 


\section{Introduction}

Atmospheric aerosols influence the Earth's climate both directly and indirectly through affecting the radiation balance, and altering the albedo, lifetime and precipitation patterns of clouds (IPCC, 2013). However, uncertainty in the spatial and temporal variability in the aerosol size distribution, chemical composition and physicochemical properties make it difficult to quantify the aerosol climate effects. The physicochemical properties of atmospheric aerosol populations vary (e.g., Jimenez et al., 2009). In terms of aerosol chemical composition measurements, one of the greatest challenges is the presence of a vast number of different organic components in the particles (Kanakidou et al., 2005; Goldstein and Galbally, 2007); Kroll et al., 2011; Donahue et al., 2013). Understanding of the chemical and physical properties of these organic compounds remains incomplete (Hallquist et al., 2009).

One of the key physicochemical properties of atmospheric organic compounds is their volatility, which determines their partitioning between the gas and particle phase (Pankow, 1994; Bilde et al., 2015). Atmospheric aerosol particles are mixtures of organic and inorganic compounds with different volatilities. Volatilities of the common inorganic species are relatively well known, while information on the volatility of organic species, especially on extremely low volatility organics (Ehn et al., 2014; Bilde et al., 2015), is still incomplete.

Different compounds evaporate differently at different temperatures depending on their volatilities, described with saturation vapor concentrations and enthalpies of vaporization (Kreidenweis et al., 1998). Therefore, measuring the evaporation of particles at different temperatures provides indirect information on the volatility of particles. Thermodenuders (TD) where particle populations are heated, often coupled with a tandem differential mobility analyzer (TDMA), are often used to obtain volatility information on particles. More quantitative information on the volatility distribution can be further obtained by coupling the measurement data with a kinetic evaporation model (e.g., Riipinen et al., 2010; Cappa and Jimenez, 2010) that describes the evaporation rate of aerosols inside the TD. While the combination of different TD setups has been applied to quantify the volatility of laboratory-generated aerosol particles (e.g., Häkkinen et al., 2014) as well as field observations (e.g., Lee et al., 2010; Cappa and Jimenez, 2010; Häkkinen et al., 2012), it has not been utilized to determine the volatility distribution of ambient organic aerosol in a boreal environment. Here, it needs to be noted that the volatility distribution of ambient aerosols does not represent the volatility distribution of the condensing organic compounds in the gaseous phase. However, it provides insights into the evaporation potentials of the compounds that are present in the particle phase. Furthermore, it will be useful for closure studies combining this information with condensation studies aiming to derive how the aerosol size distributions are affected by given gaseous species. Finally, measuring the evaporation of aerosols is also essential for testing the applicability and limitations of TD setups for inferring the volatility of aerosols.

Positive matrix factorization (PMF) is one of the widely used factor analysis techniques for environmental applications. PMF allows separating organic aerosol (OA) mass spectra into individual groups based on their bulk chemical characteristics, providing information on the OA sources and atmospheric processing (Lanz et al., 2007; Huffman et al., 2009; Zhang et al., 2011). Typical organic groups determined using the PMF analysis include e.g., hydrocarbonlike OA (HOA), biomass burning OA (BBOA) and cooking OA (COA) or oxygenated OA (OOA). OOA can be further separated into low-volatility OOA (LV-OOA) and semivolatile OOA (SV-OOA). Even though there have been multiple studies using PMF to identify different organic OA groups from ambient data (Ulbrich et al., 2009; Hildebrandt et al., 2010; Ng et al., 2010), especially the SV-OOA and LVOOA groups, to our knowledge there are only few studies (Cappa and Jimenez, 2010; Paciga et al., 2016) that have attempted to directly connect the oxygenation levels from these two OOA groups with the volatility of OA obtained by other methods. Comparing the volatility distribution obtained using a mass transfer model and VTDMA data to the oxidation level derived from the AMS data using PMF can help in quantifying the volatilities of SV-OOA and LV-OOA.

In this study, we provide quantitative information on volatility distributions of organic species of ambient aerosol in a boreal forest environment. The sensitivity of the kinetic model was tested towards different parameters of organic compounds, including density, molar mass, saturation vapor concentration, diffusion coefficient and vaporization enthalpy values. More specifically, the sensitivity result to assumed vaporization enthalpy values of organics is discussed. The VTDMA-derived volatility distributions are compared with the ones obtained from the statistical analysis of the AMS.

\section{Methods}

\subsection{Measurements site}

The measurements were performed at the Hyytiälä SMEAR II (Station for Measuring Ecosystem-Atmosphere Relations II) between 14 April and 31 May 2014. The SMEAR II station, located in southern Finland, is surrounded by a 54-year-old pine forest (Hari and Kulmala, 2005). The closest large city is Tampere, with a population of around 213000 and about $48 \mathrm{~km}$ to the southwest of the measurement station.

A series of ambient parameters - e.g., particle number size distribution of 3-1000 nm particles (Aalto et al., 2001); ambient meteorological conditions such as temperature, relative humidity, solar radiation, wind speed and wind direction; and 
gas phase concentrations of, for example, $\mathrm{SO}_{2}, \mathrm{O}_{3}, \mathrm{NO}_{x}-$ are continuously measured at the station.

\subsection{Particle volatility}

The evaporation behavior of submicron aerosols was investigated using a volatility tandem differential mobility analyzer (VTDMA), which is part of a volatility-hygroscopicity tandem differential mobility analyzer (VH-TDMA) system (Hong et al., 2014). A brief schematic view of the VTDMA is shown in Fig. 1. In brief, a monodisperse aerosol population (particle diameter of 30,60, 100 and $145 \mathrm{~nm} ; \mathrm{RH}<10 \%$ ) was selected by a Hauke-type differential mobility analyzer (DMA; Winklmayr et al., 1991). The aerosol flow was then heated by a thermodenuder at a set temperature, after which the remaining aerosol material was introduced into a second DMA followed by a condensation particle counter (CPC, TSI 3010 and TSI 3772), where the number size distribution of the aerosol after heating was measured. The spread of the number size distribution of the aerosol was taken into account in the data inversion using the piecewise linear inversion approach (Gysel et al., 2009). The thermodenuder is a $50 \mathrm{~cm}$ stainless steel tube. No adsorptive material for removing the gas phase was used after the heating section. The residence time inside the thermodenuder was around $2.5 \mathrm{~s}$. The heating temperature of the setup ramped up from 25 to $280^{\circ} \mathrm{C}$ with a time resolution of about an hour. It was assumed that the particles were instantaneously thermally equilibrated with the surrounding gas phase, as the system was under atmospheric pressure.

The major particle losses during the heating process are from thermophoresis and Brownian diffusion (Wehner et al., 2002; Häkkinen et al., 2012). According to Ehn et al. (2007), who used a similar TD, the losses for aerosol particles above $15 \mathrm{~nm}$ in diameter were observed to be less than $20 \%$ when heated to $280^{\circ} \mathrm{C}$. Due to these losses, the VTDMA-measured data underestimate the mass concentration of the monodisperse aerosol particles after heating. However, this study focused on the change in particle size, which should not be greatly affected by the losses. Hence, the effect of the particle losses on the study results can be considered negligible.

The VTDMA measures the particle diameter (and concentration) after heating at each temperature for particles of certain initial size. From this information volume fraction remaining (VFR) after the heating of particles of diameter $D_{\mathrm{P}}$ can be defined as follows:

$\operatorname{VFR}\left(D_{\mathrm{P}}\right)=\frac{D_{\mathrm{p}}^{3}(T)}{D_{\mathrm{p}}^{3}\left(T_{\text {room }}\right)}=\mathrm{GF}_{V}^{3}(T)$.

$\mathrm{GF}_{V}$ describes how much of the particles shrink in size upon heating. With $\mathrm{VFR}=1$ at a given temperature, particles are considered to not evaporate, while with $\mathrm{VFR}=0$ particles fully evaporate upon heating at that temperature. The mass fraction remaining (MFR) after the heating was assumed to be equivalent to VFR assuming that particle density was constant upon heating (Häkkinen et al., 2012).

Data during a running time window $(5 \mathrm{~h})$ were inserted into the model with a time resolution of half an hour to make sure a full thermogram, i.e., the VFR or MFR as a function of temperature, could be obtained. The corresponding results represented the conditions (VFR or MFR) at the median time of the $5 \mathrm{~h}$ time window.

\subsection{Particle chemical composition}

A high-resolution aerosol mass spectrometer (HR-AMS, Aerodyne Research Inc., Billerica, USA) was used to determine the chemical composition of aerosol particles during the experimental period. Detailed description of the instrument, measurement and data processing can be found in other publications (DeCarlo et al., 2006; Canagaratna et al., 2007). A Sunset semi-continuous OC / EC analyzer was deployed to determine the mass concentrations of organic carbon (OC) and elemental carbon (EC) concentrations in aerosols using a thermal-optical protocol (Bauer et al., 2009).

\subsubsection{Pairing of inorganic species}

The neutral inorganic salts were calculated from the molar concentration of all ions measured by the HR-AMS based on ion-pairing schemes introduced by Reilly and Wood (1969) and Gysel et al. (2007). $\mathrm{SO}_{4}^{2-}$ was first neutralized by $\mathrm{NH}_{4}^{+}$, and the excess of $\mathrm{NH}_{4}^{+}$was then used to neutralize $\mathrm{NO}_{3}^{-}$. The simplified ion-paring scheme was introduced as below:

$$
\begin{aligned}
& n_{\mathrm{H}_{2} \mathrm{SO}_{4}}=\max \left(0, n_{\mathrm{SO}_{4}^{2-}}-n_{\mathrm{NH}_{4}^{+}}\right), \\
& n_{\mathrm{NH}_{4} \mathrm{HSO}_{4}}=\min \left(2 n_{\mathrm{SO}_{4}^{2-}}-n_{\mathrm{NH}_{4}^{+}}, n_{\mathrm{NH}_{4}^{+}}\right), \\
& n_{\left(\mathrm{NH}_{4}\right)_{2} \mathrm{SO}_{4}}=\min \left(\max \left(n_{\mathrm{NH}_{4}^{+}}-n_{\mathrm{SO}_{4}^{2-}}, 0\right), n_{\mathrm{SO}_{4}^{2-}}\right), \\
& n_{\mathrm{NH}_{4} \mathrm{NO}_{3}}=\min \left(\max \left(n_{\mathrm{NH}_{4}^{+}}-2 n_{\mathrm{SO}_{4}^{2-}}, 0\right), n_{\mathrm{NO}_{3}^{-}}\right),
\end{aligned}
$$

where $n$ denotes the number of moles. This should naturally be treated only as a rough estimation, as the scheme assumes perfectly internally mixed particles, and the competing bonding of $\mathrm{NH}_{4}^{+}$between $\mathrm{SO}_{4}^{2-}$ and $\mathrm{NO}_{3}^{-}$in particle phase is not fully described.

\subsubsection{Positive matrix factorization (PMF) of organic aerosol composition}

Factor analysis is commonly used to de-convolve the timedependent OA concentrations and mass spectra into their basic components, based on a linear algebraic model explaining the observed variance. The resulting components, i.e., factors, are interpretable as separate organic sub-groups. The sum of these organic groups' concentrations should closely match the measured organic aerosol mass. PMF (Paatero, 1997) is one of these component analysis techniques, constrained so that only positive concentration and mass spectra 


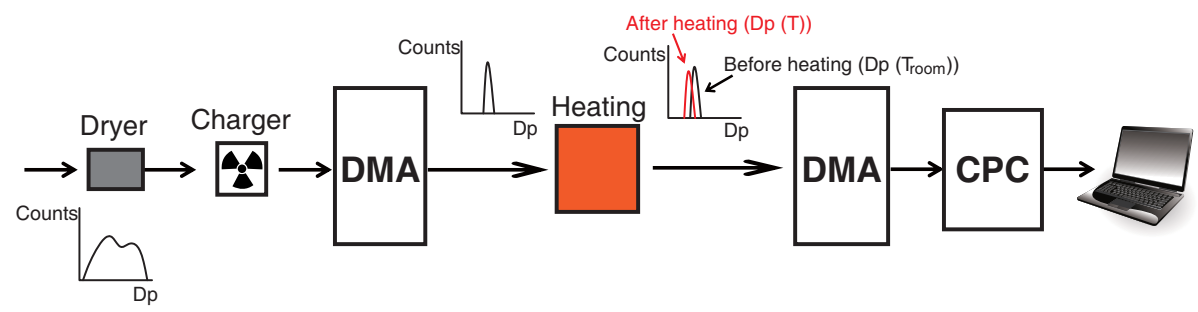

Figure 1. Schematic view of the VTDMA system.

are obtained. In this study, PMF was applied by using the PMF2 algorithm implemented with the user interface Sofi by Canonaco et al. (2013) to the organic aerosol data measured by the HR-AMS.

\subsection{Kinetic evaporation model}

A time-dependent evaporation model (Riipinen et al., 2010) was used to simulate the evaporation of a monodisperse aerosol population in a heated flow tube by solving the relevant mass transfer equations. The TD temperature profile, residence time, initial particle size and the thermophysical properties of the aerosol particles were used as input to the model. The volatility of the aerosol constituents was described by the effective saturation concentration, $C^{*}$, at standard conditions.

According to Donahue et al. (2013) and Murphy et al. (2014), compounds with different effective saturation vapor concentrations can be classified into extremely low volatility (ELVOC; $\quad C^{*}<10^{-4} \mu \mathrm{g} \mathrm{m}^{-3}$ ), low-volatility (LVOC; $10^{-3} \mu \mathrm{g} \mathrm{m}^{-3}<C^{*}<10^{-1} \mu \mathrm{g} \mathrm{m}^{-3}$ ), semi-volatile (SVOC; $\left.10^{-0.5} \mu \mathrm{g} \mathrm{m}^{-3}<C^{*}<10^{2.5} \mu \mathrm{g} \mathrm{m}^{-3}\right)$ and intermediatevolatility (IVOC; $10^{2.5} \mu \mathrm{g} \mathrm{m}^{-3}<C^{*}<10^{6.5} \mu \mathrm{g} \mathrm{m}^{-3}$ ) organic compounds. In the model, we assume the OA to consist of three organic groups with their individual characteristic saturation concentration of $10^{-5}$ (ELVOA), $10^{-2}$ (LVOA) and $10 \mu \mathrm{g} \mathrm{m}^{-3}$ (SVOA), corresponding to $10^{-10}, 10^{-7}$, and $10^{-5} \mathrm{~Pa}$ or $10^{4}, 10^{7}$, and $10^{10}$ molec $\mathrm{cm}^{-3}$ : the aim being to obtain the particle mass fractions of each of the organic group. The ambient particles were assumed to be a mixture of six species, including the aforementioned organic groups and three inorganic components, namely ammonium nitrate (AN), ammonium sulfate (AS) and EC. AN and AS were assigned with their own characteristic effective saturation vapor concentration and effective vaporization enthalpies obtained from laboratory measurements (see Table 1). EC was assumed to be non-volatile in the temperature range used in this study (assuming $C^{*}$ of $10^{-30} \mu \mathrm{g} \mathrm{m}^{-3}$ ). As a result, the corresponding average volatility distribution of the ambient aerosol was obtained by letting the difference between the measured and modeled evaporation of the ambient aerosol to reach a minimum with a certain pair of mass fractions of these three organic groups together with known mass fractions of AS, AN and EC from HR-AMS and OC/EC measurements. The MATLAB optimization function fmincon with constraints was used to obtain the optimal fit between the measured and modeled thermograms. This optimization method was constrained by setting the sum of mass fraction of organics from the model to be equal to the mass fraction of OA measured by HR-AMS and the mass fraction of each individual organic group to be larger than zero but lower than the total measured mass fraction of OA.

The input parameters, including the physicochemical properties of the six components used for the model as well as particle properties, are summarized in Table 1. Specifically, a mass accommodation coefficient of unity was used along the whole study, thus yielding the maximum estimates for $C^{*}$ s. To best match the overlapping size ranges of the instruments (VTDMA 30-145 nm and HR-AMS 60-1000 nm), in this study we focus on modeling the evaporation of $100 \mathrm{~nm}$ particles.

Lee et al. (2010) reported that the modeled MFR is likely to depend strongly on the vaporization enthalpy values. Hence, sensitivity tests towards this variable were performed. In the sensitivity analysis the vaporization enthalpy values of organics with different volatilities were either assumed to be the same or varied for the different organics, e.g., [100 80 $60] \mathrm{kJ} \mathrm{mol}^{-1}$. Epstein et al. (2010) fitted the average $\Delta H_{\mathrm{VAP}}$ as a function of $\log _{10} C^{*}$ to a set of surrogate organic compounds and obtained the following relationship:

$\Delta H_{\mathrm{VAP}}=-11 * \log _{10} C^{*}+129$,

where $\Delta H_{\mathrm{VAP}}$ and $C^{*}$ are in units of $\mathrm{kJ} \mathrm{mol}^{-1}$ and $\mu \mathrm{g} \mathrm{m}^{-3}$, respectively. This vaporization enthalpy $\left(\Delta H_{\mathrm{VAP}}\right)$ of Epstein et al. (2010) (Eq. 3) was also tested in the model calculations. The combinations of enthalpy values of all these three organic groups used in this study are summarized in Table 2 .

\section{Results and discussion}

\subsection{Inorganic volatility}

Figure 2 illustrates the measured and model-interpreted thermograms (i.e., MFR as a function of the heating temperature) of ammonium nitrate and ammonium sulfate. Vallina et 
Table 1. Properties of six particle components used as input for the evaporation model.

\begin{tabular}{|c|c|c|c|c|c|c|}
\hline Model input parameter & ELVOA & LVOA & SVOA & $\begin{array}{l}\text { Ammonium } \\
\text { nitrate (AN) }\end{array}$ & $\begin{array}{l}\text { Ammonium } \\
\text { sulfate (AS) }\end{array}$ & $\begin{array}{r}\text { Elemental } \\
\text { carbon }(\mathrm{EC})\end{array}$ \\
\hline Molar mass, $M_{\mathrm{W}}\left(\mathrm{g} \mathrm{mol}^{-1}\right)$ & 300 & 200 & 150 & 80 & 132 & 280 \\
\hline Density, $\rho\left(\mathrm{kg} \mathrm{m}^{-3}\right)$ & 1900 & 1700 & 1400 & 1720 & 1770 & 1900 \\
\hline Surface tension, $\sigma\left(\mathrm{N} \mathrm{m}^{-1}\right)$ & 0.05 & 0.05 & 0.05 & 0.05 & 0.05 & 0.05 \\
\hline Diffusion coefficient, $D\left(10^{-6} \mathrm{~m}^{2} \mathrm{~s}^{-1}\right)$ & 5 & 5 & 5 & 5 & 5 & 5 \\
\hline Temperature-dependent factor for $D, \mu$ & 1.75 & 1.75 & 1.75 & 1.75 & 1.75 & 1.75 \\
\hline Saturation vapor concentration, $C^{*}\left(\mu \mathrm{g} \mathrm{m}^{-3}\right)$ & $1 \times 10^{-5}$ & $1 \times 10^{-2}$ & 10 & 76 & $2.0 \times 10^{-3}$ & $1 \times 10^{-30}$ \\
\hline Enthalpy of vaporization, $\Delta H_{\mathrm{VAP}}\left(\mathrm{kJ} \mathrm{mol}^{-1}\right)$ & $-^{\mathrm{a}}$ & $-^{\mathrm{a}}$ & $-^{\mathrm{a}}$ & 152 & 94 & 100 \\
\hline Mass accommodation coefficient, $\alpha_{\mathrm{m}}$ & 1 & 1 & 1 & 1 & 1 & 1 \\
\hline Activity coefficient, $\gamma$ & 1 & 1 & 1 & 1 & 1 & 1 \\
\hline Particle mass for the monodisperse aerosols, $m_{\mathrm{P}}\left(\mu \mathrm{g} \mathrm{m}^{-3}\right)^{\mathrm{b}}$ & 0.1 & & & & & \\
\hline Particle mobility diameter, $D_{\mathrm{P}}(\mathrm{nm})$ & 100 & & & & & \\
\hline
\end{tabular}

a The chosen enthalpy values of three groups of organics are summarized in Table $2 .{ }^{\mathrm{b}}$ The particle mass concentration in particle size bin of $90-110 \mathrm{~nm}$ from DMPS is used to represent the particle mass concentration of the monodisperse aerosols (i.e., $D_{\mathrm{P}}=100 \mathrm{~nm}$ ).

Table 2. The combinations of vaporization enthalpy values used as an input for the evaporation model.

\begin{tabular}{lrrr}
\hline & ELVOA & LVOA & SVOA \\
\hline Combination 1 & 60 & 60 & 60 \\
Combination 2 & 80 & 80 & 80 \\
Combination 3 & 100 & 100 & 100 \\
Combination 4 & 100 & 80 & 60 \\
Combination 5 & 120 & 100 & 80 \\
Combination 6 & 130 & 110 & 80 \\
Combination 7 & 160 & 130 & 80 \\
Combination 8 & 140 & 125 & 100 \\
Combination 9 & Eq. (3) & Eq. (3) & Eq. (3) \\
\hline
\end{tabular}

al. (2007) reported that for $150 \mathrm{~nm}$ AN and AS particles, the volatilization temperatures (temperature of full particle evaporation) are around 60 and $180^{\circ} \mathrm{C}$, respectively, by using a similar VTDMA system with a residence time of around one second. According to the experimental curves (black line) in Fig. 2, AN and AS evaporated completely at around 45 and $180^{\circ} \mathrm{C}$, respectively. These results are close to those of Vallina et al. (2007) when the effects of faster evaporation for smaller particles and longer residence time of this study are taken into account.

Modeled thermograms for both AN and AS were obtained by treating the saturation vapor pressures and enthalpy of vaporization as fitting parameters. The optimum $C^{*}-\Delta H_{\mathrm{VAP}}$ pair was obtained by minimizing the difference between the measured and model-interpreted thermograms (red lines in Fig. 2). The measured evaporation of AN was reproduced using $C^{*}$ and $\Delta H_{\mathrm{VAP}}$ of $76 \mu \mathrm{g} \mathrm{m}^{-3}$ (corresponding to $2.6 \times 10^{-3} \mathrm{~Pa}$ ) and $152 \mathrm{~kJ} \mathrm{~mol}^{-1}$, respectively. The obtained $\Delta H_{\mathrm{VAP}}$ is 1.5 times higher than reported previously (Brandner et al., 1962; Hildenbrand et al., 2010a, b; Salo et al., 2011), and the saturation vapor concentration
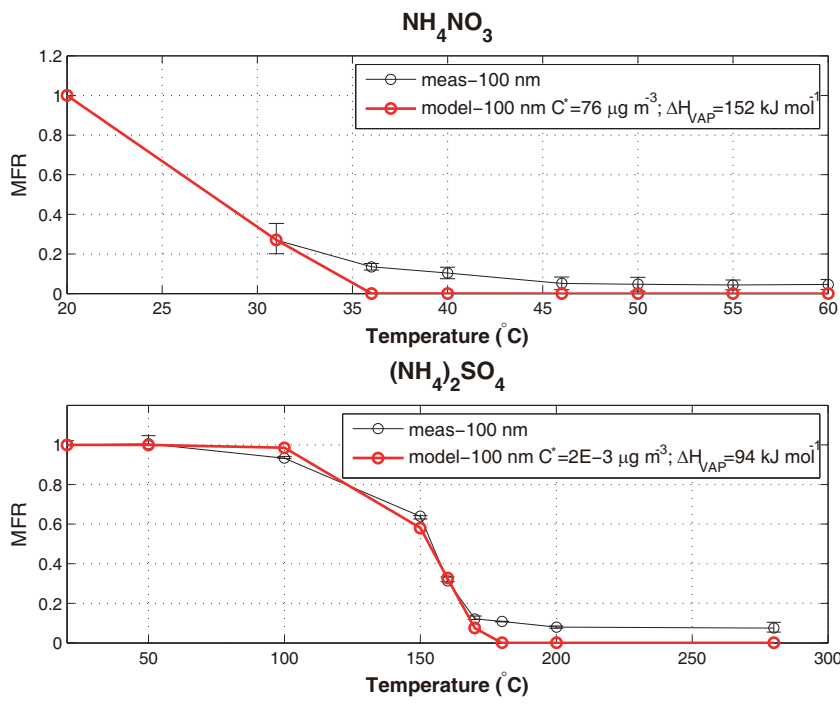

Figure 2. Thermograms of ammonium nitrate and ammonium sulfate using the VTDMA (black lines) and the modeled evaporation using saturation vapor pressures and enthalpies of vaporization corresponding to the best fit with the experimental data (red lines).

is of the same magnitude as in previous studies (Brandner et al., 1962; Chien et al., 2010). For AS, $C^{*}$ and $\Delta H_{\mathrm{VAP}}$ of $2 \times 10^{-3} \mu \mathrm{g} \mathrm{m}^{-3}$ and $\Delta H_{\mathrm{VAP}}$ of $94 \mathrm{~kJ} \mathrm{~mol}^{-1}$ reproduced the measurements best. Chien et al. (2010) reported an observation of AN partially decomposing to $\mathrm{NH}_{3}$ and $\mathrm{HNO}_{3}$ upon heating. Huffman et al. (2009) similarly suggested that AS might decompose to ammonium bisulfate and ammonia when heating to around $90-140^{\circ} \mathrm{C}$. The evaporation mechanisms of these inorganics might be different from the evaporation of organics, where the $\Delta H_{\mathrm{VAP}}$ of Epstein et al. (2010) was obtained since, besides sublimation, decomposition might also occur during the evaporation of inorganics. Hence, the vaporization enthalpy from Eq. (3) is not used 


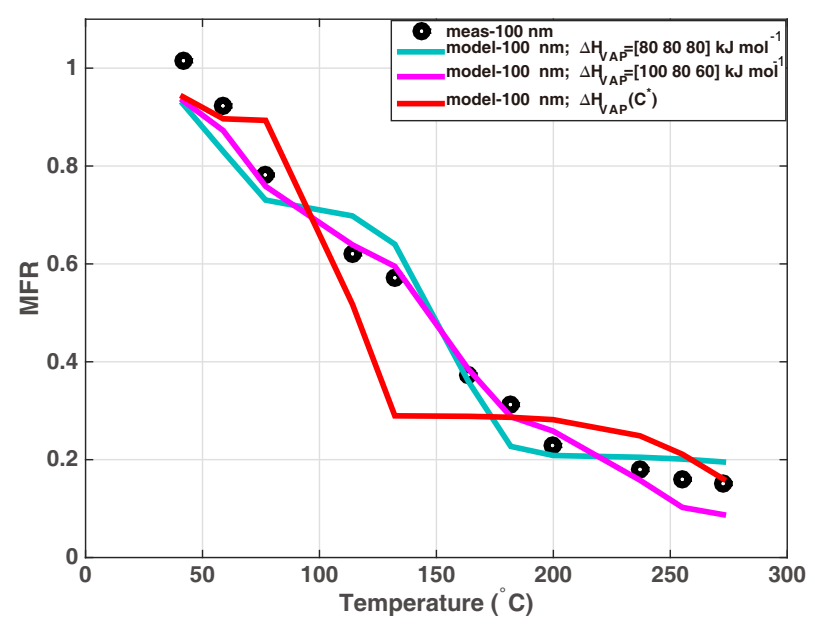

Figure 3. An example of measured (black dots) vs. modeled (green, magenta and red lines) thermograms assuming different vaporization enthalpies of the organics.

for the simulation of the evaporation of inorganics. In short, even though there have been aforementioned earlier studies reporting the $C^{*}$ and $\Delta H_{\mathrm{VAP}}$ of $\mathrm{AN}$ and $\mathrm{AS}$, we selected the ones shown by the red curves in Fig. 3 from our VTDMA technique for the model input to simulate the evaporation of ambient aerosols. Moreover, according to the saturation vapor concentration obtained for AN and AS in this study, we can conclude that AN and AS can be considered as semivolatile and low-volatility compounds, respectively.

The measured thermogram and corresponding evaporation mechanism of ammonium bisulfate $\left(\mathrm{NH}_{4} \mathrm{HSO}_{4}\right)$ are not available at present. In order to neglect the effect of ammonium bisulfate on particle evaporation behavior, only data with the mass fraction of ammonium bisulfate less than $10 \%$ of total aerosol mass (calculated from Eq. 2) were analyzed.

\subsection{Performance of the model for TD data on the organic mixtures}

Figure 3 shows example fits to the observed thermograms using different combinations of organic vaporization enthalpies (Table 2). The different simulated evaporation behavior indicates that the model is sensitive to $\Delta H_{\mathrm{VAP}}$ values. The median norm of residuals, which describes the difference between the fit and observed thermograms, was the largest when the $\Delta H_{\mathrm{VAP}}$ of Epstein et al. (2010) (e.g., Combination 9 in Table 2) for organics were applied in the model. As $\Delta H_{\mathrm{VAP}}$ increases, the sensitivity of $C^{*}$ to temperature changes also increases, requiring also lower $C^{*}$ values to match observations (see the red curve in Fig. 3). This is also in line with Cappa and Jimenez (2010), who suggested that value of $C^{*}$ as low as $10^{-15} \mu \mathrm{g} \mathrm{m}^{-3}$ for extremely low volatility material is required to match the observations when $C^{*}$-dependent vaporization enthalpy values of Epstein et al. (2010) are used.
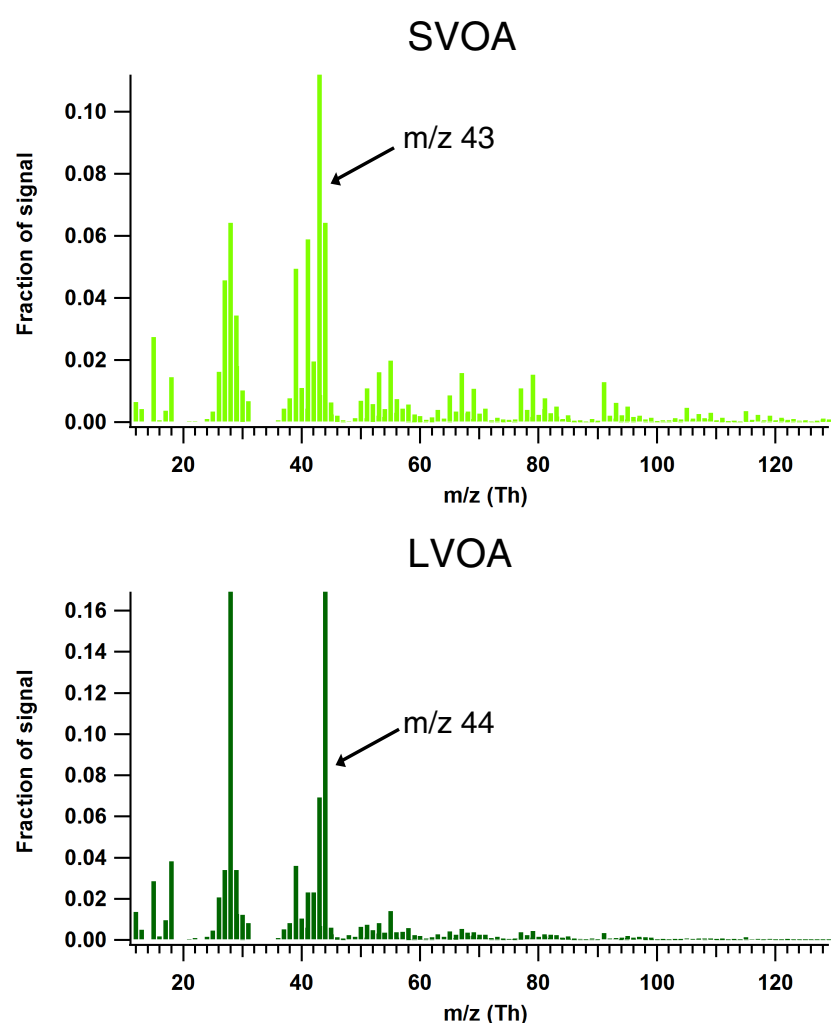

Figure 4. Mass spectrum of SVOA and LVOA obtained from the PMF analysis (two-factor solution).

By using the other vaporization enthalpy values (e.g., Combinations 1 to 8 in Table 2), better agreement between the fitted and observed thermograms (Fig. 3) was obtained. Donahue et al. (2006) pointed out that artificially low $\Delta H_{\mathrm{VAP}}$ values are expected when we present the complex organic mixture aerosol with one single organic compound or of very few components. The artificially low $\Delta H_{\mathrm{VAP}}$ values should thus be rather referred to effective enthalpy of vaporization (see, e.g., Offenberg et al., 2006). According to the performance of the model to TD data, the model was observed to be sensitive to $\Delta H_{\mathrm{VAP}}$ values. Low $\Delta H_{\mathrm{VAP}}$ values (i.e., $\Delta H_{\mathrm{VAP}}=60-80 \mathrm{~kJ} \mathrm{~mol}^{-1}$ ) are suggested to be used in the model in order to reproduce the measured thermograms.

\subsection{AMS-derived volatility distribution using PMF}

Two organic aerosol groups (SVOA and LVOA) with different volatilities were separated from the AMS data using the PMF method (Sect. 2.3.2). This common two-factor separation is driven by the relative fractions of $m / z 44(f 44)$ and $m / z 43$ (f43), connected to the oxidation state (e.g., Aiken et al., 2008). Higher factor solutions associated with other organic groups, commonly determined by PMF analysis, such as biomass burning organic aerosol or hydrocarbon-like organic aerosol, were not pursued. Since this study focuses on the volatility distribution of organics using a complex kinetic 

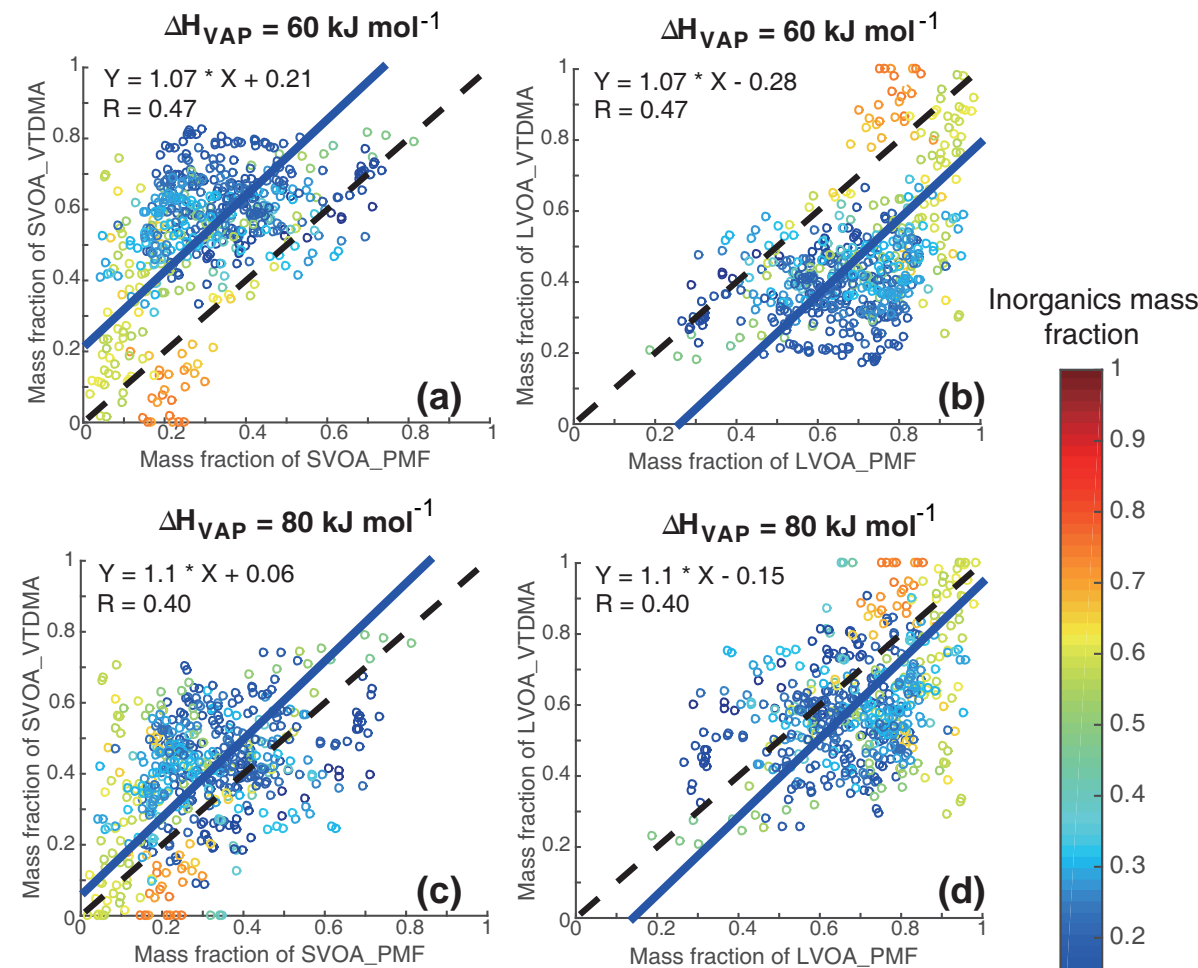

$-0.8$
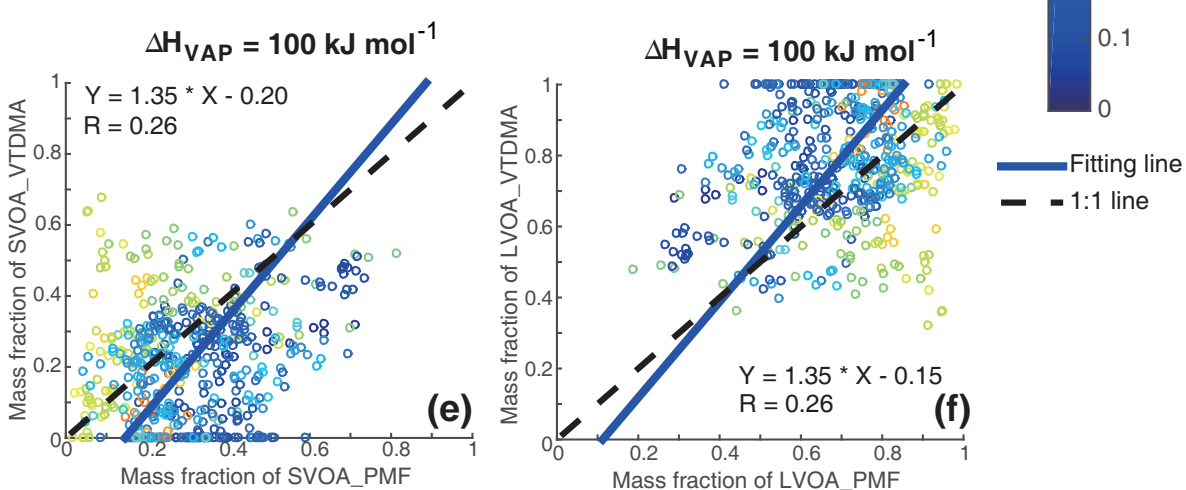

Figure 5. Mass fractions of SVOA and LVOA of the total organic mass obtained from VTDMA data vs. the ones from the PMF analysis. Here, the $y$ axis represents the VTDMA results interpretation using the kinetic model and the $x$ axis represents the AMS results interpretation using the statistical model (PMF). Model results were obtained by using a constant enthalpy value for all organics, corresponding to Combination 1 (a and b), Combination 2 (c and $\mathbf{d}$ ) and Combination 3 (e and $\mathbf{f}$ ) in Table 2. The LVOA_VTDMA here is the sum of LVOA and ELVOA mass fractions. The colors of the data points illustrate the inorganic mass fraction in the particles. Correlation coefficient and equation for the line fitted to the data points are given in the legends.

model, we chose to limit the PMF OA components to the main ones clearly connected with oxidation state.

The mass spectra of the two organic groups are shown in Fig. 4. The LVOA mass spectrum shows a highly abundant $m / z \quad 44$ signal, which mostly corresponds to the $\mathrm{CO}_{2}^{+}$ion (Aiken et al., 2008). The mass fraction of $\mathrm{m} / z 44$ shows a good correlation with the $\mathrm{O}: \mathrm{C}$ ratio in the organic aerosols (Aiken et al., 2008). The SVOA mass spectrum has a high signal at $m / z 43$, corresponding to the $\mathrm{C}_{2} \mathrm{H}_{3} \mathrm{O}^{+}$ion, which is often considered as a proxy for less oxidized organic aerosol. Hence, the relative abundances of ions at $m / z, 43(f 43)$ and $m / z 44(f 44)$ are our main indicators to separate these two organic groups with different volatilities arising from their different degrees of oxygenation.

Paciga et al. (2016) studied the volatility distribution of an LVOA factor determined by the PMF analysis and found that a significant amount of the LVOA mass was attributable to ELVOCs with effective saturation concentrations $\leq 10^{-3} \mu \mathrm{g} \mathrm{m}^{-3}$. Hence, probably further advances in the PMF analysis would be needed to assign more than two groups of OA. We tested a three-factor application of PMF, based on the ratio of masses of ions between $\mathrm{m} / \mathrm{z} 44$ and 


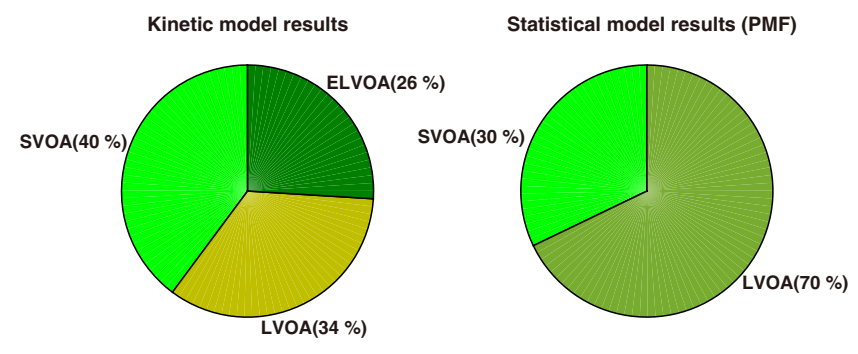

Figure 6. Median organic volatility distribution of the ambient aerosols of this study obtained from the VTDMA data interpreted by the kinetic evaporation model (Riipinen et al., 2010) and the AMS data derived from the PMF analysis. $\Delta H_{\text {Vap }}=80 \mathrm{~kJ} \mathrm{~mol}^{-1}$ was used in the kinetic evaporation model.

$m / z 43$, and compared the resulting three organics factors with the mass fractions of different organics from the VTDMA data. There was no correlation $(R=0.02)$ between the mass fraction of LVOA from the model and any of three factors from PMF analysis. We are not confident to explain the reason behind this, but it seems possible that the mass spectral statistics based on the PMF classification does not match with the actual volatility grouping. The following discussion thus only focuses on the well-established two-factor PMF solution (SVOA, LVOA) for the organic components.

\subsection{Comparison between organic aerosol volatility from VTDMA and PMF analysis}

\subsubsection{General results}

In Fig. 5, we compare the organic volatility distributions obtained from the VTDMA data using constant $\Delta H_{\mathrm{VAP}}$ values (Combinations 1 to 3 in Table 2) with PMF analysis results. Since we used PMF-derived two-factor results, we summed up the mass fractions of LVOA and ELVOA from the VTDMA for the comparison. The correlation coefficients for the two data sets were relatively similar with $\Delta H_{\mathrm{VAP}}$ values of $60 \mathrm{~kJ} \mathrm{~mol}^{-1}(R=0.48)$ and $80 \mathrm{~kJ} \mathrm{~mol}^{-1}$ assumed for all organic groups $(R=0.41)$. Using $\Delta H_{\mathrm{VAP}}$ of $100 \mathrm{~kJ} \mathrm{~mol}^{-1}$ for all organic groups leads to a clearly worse correlation $(R=0.25)$ and the model interpreted that the particles were solely consisting of low volatility organics besides the inorganic species. Using the enthalpy value of $60 \mathrm{~kJ} \mathrm{~mol}^{-1}$ for all organic groups, the modeled mass fraction of SVOA was higher than the SVOA from the PMF analysis. The opposite was true for LVOA; while using $\Delta H_{\mathrm{VAP}}$ values of $100 \mathrm{~kJ} \mathrm{~mol}^{-1}$ for all organic groups, the comparison results differed significantly from the $1: 1$ line. With the enthalpy value of $80 \mathrm{~kJ} \mathrm{~mol}^{-1}$ for organics, the VTDMA-based OA composition was approximately equal to the ones from the PMF results, however, with a linear correlation coefficient of only 0.4 . This relatively low correlation coefficient suggests that additional information on each of the methods is needed for analyzing the potential links between the AMS and volatility data. Moreover, Paciga et al. (2016) studied the volatility distribution of the PMF-derived organics and estimated that almost half of the SVOCs, which were determined from PMF, are semi-volatile, while $42 \%$ are lowvolatility and $6 \%$ are extremely low volatility. This suggests that the two PMF-derived organic groups, commonly labeled for their oxidation levels, might not be directly linked to their actual volatilities.

The agreement between the VTDMA- and PMF-based OA volatility distributions depends on the inorganic mass fractions. The agreement tended to be somewhat better when the inorganic mass fraction was lower (see Fig. S1 in the Supplement). Interestingly, when the inorganic mass fraction was lower than 0.3 , the modeled results correlated well with the PMF results, with $\Delta H_{\mathrm{VAP}}$ values of $100 \mathrm{~kJ} \mathrm{~mol}^{-1}$ used in the model. Results of Häkkinen et al. (2014) suggested that relatively more particle-phase processing, i.e., condensed-phase reactions, take places within organic-inorganic aerosol mixtures having a higher aerosol inorganic mass fraction - which could be consistent with our results as well.

The use of varying $\Delta H_{\mathrm{VAP}}$ values for ELVOA, LVOA and SVOA did not improve the correlation with the PMF results (see Figs. S2 and S3). Specifically, using $\Delta H_{\mathrm{VAP}}$ values from Eq. (3) would result in particles exclusively consisting of low-volatility organics besides the inorganic species. Lee et al. (2010) reached a similar conclusion. A single effective $\Delta H_{\mathrm{VAP}}$ value can thus well represent the OA mixture. Cappa and Wilson (2011) studied the volatility of secondary organic aerosol from the oxidation of $\alpha$-pinene and reached a similar conclusion: $\alpha$-pinene SOA behaved as if it were comprised of a single "meta-compound".

As discussed in Sect. 3.1 we would expect the $\Delta H_{\mathrm{VAP}}$ of Epstein et al. (2010) to be the physically most correct of the alternatives tested - at least when it comes to simple reversible evaporation. However, if there are other processes in addition to evaporation taking place in the particle phase upon heating, such as the molecular decomposition or dissociation of unstable functional groups, the model might not be able to capture the measured thermogram using Eq. (3). In this case we might end up with an overestimate in the mass fraction of extremely low-volatility organics. Donahue et al. (2006) and Riipinen et al. (2010) also discussed that the evaporation of a mixture is best approximated with considerably lower effective vaporization enthalpy than the one of a pure component aerosol. For VTDMA measurements of ambient aerosols with various compositions and external conditions, the relation between the $C^{*}$ and vaporization enthalpy values might be nonlinear and species- and/or systemdependent. Moreover, Saleh et al. (2013) reported that the evaporation of particles in laboratory experiments could be simulated using a mass accommodation coefficient much less than one. Tong et al. (2011) concluded that the diffusion coefficient of a viscous solution might affect the kinetics of evaporation of non-liquid particles, as aerosol particles in boreal forest environment are expected to be viscous according to 


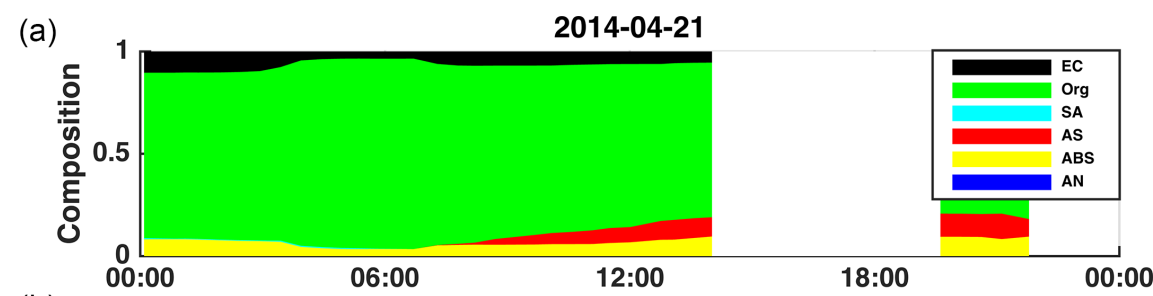

(b)
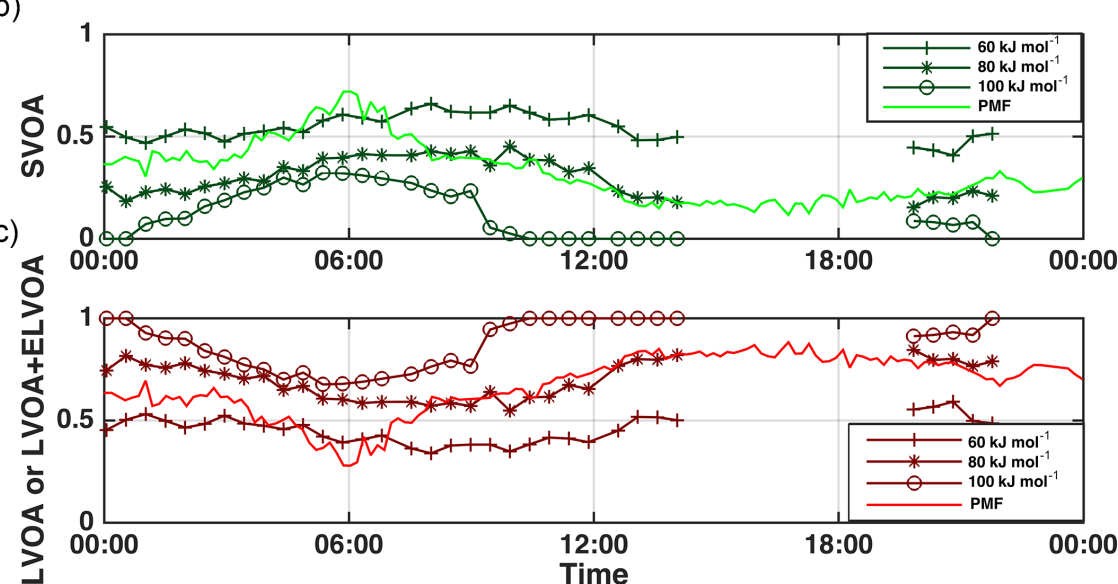

Figure 7. Time series of particle chemical composition obtained from HR-AMS (a), mass fractions of VTDMA- and PMF-derived SVOA (b) and mass fraction of VTDMA- (the sum of LVOA + ELVOA) and PMF-derived LVOA (c) on 21 April 2014.
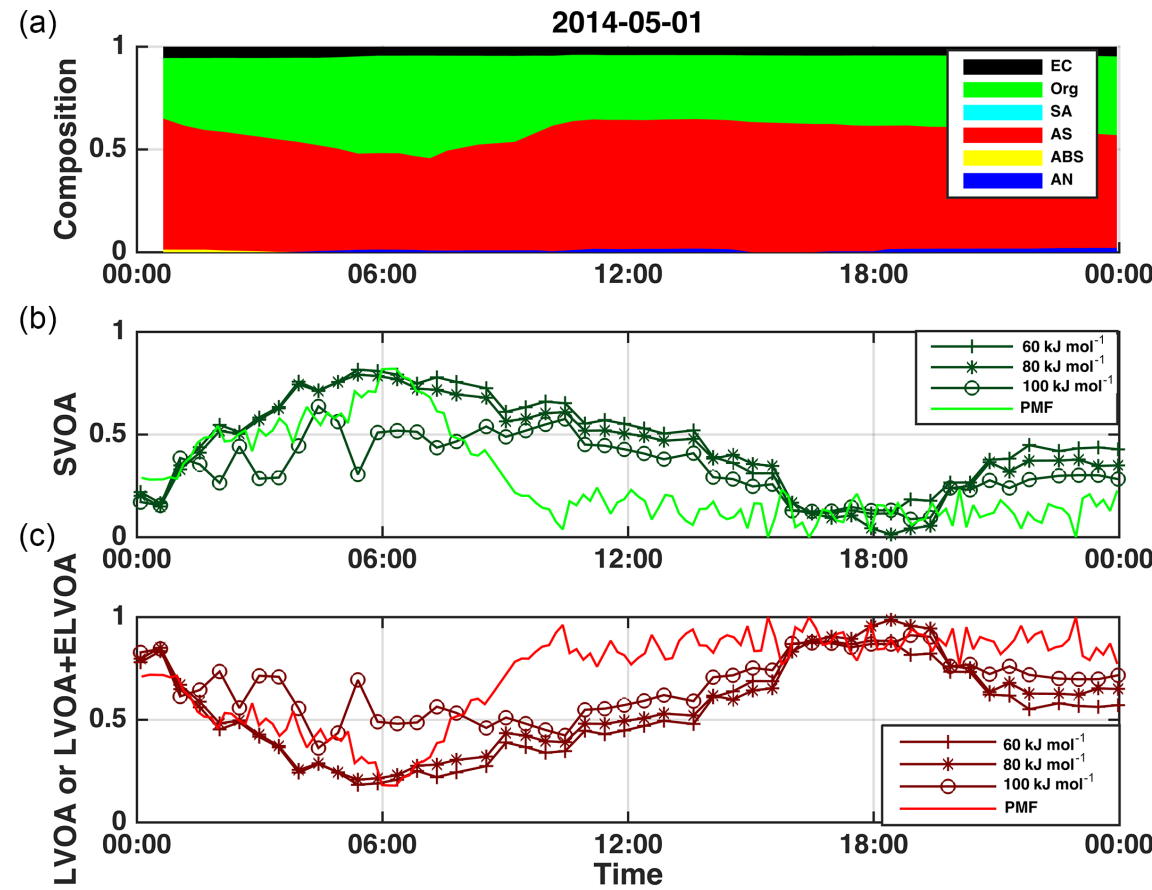

Figure 8. Time series of particle chemical composition obtained from HR-AMS (a), mass fractions of VTDMA- and PMF-derived SVOA (b) and mass fraction of VTDMA- (the sum of LVOA + ELVOA) and PMF-derived LVOA (c) on 1 May 2014. 
Virtanen et al. (2010). Hence, non-unity mass accommodation coefficients of a mixture and the particle-phase diffusion limitation on evaporation can also add uncertainties to the interpretation of the TD data.

Finally, we compared the median volatility distributions of the organics during the whole campaign using the two methods (Fig. 6). A constant $\Delta H_{\mathrm{VAP}}$ value of $80 \mathrm{~kJ} \mathrm{~mol}^{-1}$ for all organics was chosen here as the kinetic model input. According to the PMF results, the SVOA contribution to the total organic aerosol mass was around $30 \%$, which is somewhat lower than the SVOA contribution (approximately $40 \%$ ) obtained based on the VTDMA results. The model estimated that the mass fractions of LVOA and ELVOA of the total OA mass were 34 and $26 \%$, respectively.

\subsubsection{Time-dependent case studies}

Figures 7 and 8 show two case studies for 21 April and 1 May 2014. Time series of mass fractions of the particle constituents from HR-AMS, organic mass fractions from the VTDMA (using Combinations 1-3 in Table 2) and PMF analysis are shown.

When the ambient aerosol was dominated by organics (Fig. 7), the modeled SVOA mass fraction followed the temporal pattern of the one determined from PMF analysis. The elevated SVOA mass fraction in the early morning is probably due to the condensation of SVOC onto the particles when temperature was still low, and the following decrease in SVOA after the early morning could be caused by the evaporation of SVOA after the ambient temperature increased. The model-interpreted SVOA mass fraction using $\Delta H_{\mathrm{VAP}}$ values of $80 \mathrm{~kJ} \mathrm{~mol}^{-1}$ seemed to have a somewhat time-delayed effect compared with the one from the PMF analysis.

When the inorganic species dominated the ambient aerosol mass (Fig. 8), a clear diurnal pattern could also be seen from for both the VTDMA and the PMF-derived SVOA and LVOA mass fractions. However, the VTDMA-based mass fraction followed the PMF-derived ones better when using $\Delta H_{\mathrm{VAP}}$ values of 60 and $80 \mathrm{~kJ} \mathrm{~mol}^{-1}$ compared the one using $\Delta H_{\mathrm{VAP}}$ values of $100 \mathrm{~kJ} \mathrm{~mol}^{-1}$ (see also Fig. 5). The relative amount of inorganic species in the particle phase might thus affect the particle-phase processing. Conclusively, these two case studies suggest that an effective $\Delta H_{\mathrm{VAP}}$ value of $60-80 \mathrm{~kJ} \mathrm{~mol}^{-1}$ represents the boreal forest organic aerosols best and this effective $\Delta H_{\mathrm{VAP}}$ value should be assumed in the model when comparing with the PMF results.

\section{Summary and conclusions}

The volatility of ambient aerosol particles formed and undergone aging was studied with a volatility tandem differential mobility analyzer (VTDMA) in a boreal forest environment in Hyytiälä from April to May 2014. A kinetic evaporation model was used to further interpret the results and quantify the mass fraction of organics with different volatilities.

When testing the performance of the model against the experimental volatility data, the model was observed to be sensitive to the vaporization enthalpy values of the organics. $C^{*}$ dependent vaporization enthalpies based on a semi-empirical formula by Epstein et al. (2010) were applied, but the modeled thermograms failed to reproduce the measurements in this case.

The best correlation between the VTDMA results and the PMF-derived mass fractions of organics was obtained when $\Delta H_{\mathrm{VAP}}=80 \mathrm{~kJ} \mathrm{~mol}^{-1}$ was assumed for all organic groups in the model, with a linear correlation coefficient of around 0.4 . This relatively low correlation coefficient indicates that we need to acquire additional information on each of the method to address the potential relation between the AMS and volatility data.

With the use of a considerably lower enthalpy value $\left(80 \mathrm{~kJ} \mathrm{~mol}^{-1}\right)$ than the semi-empirical ones, the model can best approximate the VTDMA data and the PMF results. Potential explanations to why artificially low vaporization enthalpy values provide the best approximation include a thermal decomposition process in addition to evaporation in the particle phase, mixture effects and different mass accommodation coefficients for aerosol mixtures rather than for a pure component system (Riipinen et al., 2010). The interpretation of the VTDMA data using the kinetic evaporation model cannot provide an accurate, definitive volatility distribution for boreal forest aerosols due to the uncertainties in $\Delta H_{\mathrm{VAP}}$ and other potential issues mentioned above. However, using a proper effective $\Delta H_{\mathrm{VAP}}$ value for OA, the VTDMA-model results nevertheless, for the first time, provide a rough estimate of the volatility for boreal forest aerosols, revealing that around $26 \%$ of the monodisperse $(100 \mathrm{~nm})$ OA mass is extremely low volatility.

Data availability. The data can be accessed upon request from the corresponding author.

\section{The Supplement related to this article is available online at doi:10.5194/acp-17-4387-2017-supplement.}

Competing interests. The authors declare that they have no conflict of interest.

Acknowledgements. This work was supported by the Academy of Finland Centre of Excellence (grant no. 272041), the European Research Council (ATM-NUCLE and ATMOGAIN no. 278277), University of Helsinki funds, and the European Commission (ACTRIS, no. 262254). 
Edited by: J. Allan

Reviewed by: two anonymous referees

\section{References}

Aalto, P., Hämeri, K., Becker, E., Weber, R., Salm, J., Mäkelä, J. M., Hoell, C., O’Dowd C. D., Karlsson, H., Hansson, H.-C., Väkevä, M., Koponen, I. K., Buzorius, G., and Kulmala, M.: Physical characterization of aerosol particles during nucleation events, Tellus B, 53, 344-358, doi:10.1034/j.1600-0889.2001.530403.x, 2001.

Aiken, A. C., Decarlo, P. F., Kroll, J. H., Worsnop, D. R., Huffman, J. A., Docherty, K. S., Ulbrich, I. M., Mohr, C., Kimmel, J. R., Sueper, D., and Sun, Y.: O/C and OM/OC ratios of primary, secondary, and ambient organic aerosols with high-resolution timeof-flight aerosol mass spectrometry, Environ. Sci. Technol., 42, 4478-4485, 2008.

Bauer, J. J., Yu, X. Y., Cary, R., Laulainen, N., and Berkowitz, C.: Characterization of the Sunset Semi-Continuous Carbon Aerosol Analyzer, J. Air Waste Manage., 59, 826-833, doi:10.3155/10473289.59.7.826, 2009.

Bilde, M., Barsanti, K., Booth, M., Cappa, C. D., Donahue, N. M., Emanuelsson, E. U., McFiggans, G., Krieger, U. K., Marcolli, C., Topping, D., Ziemann, P., Barley, M., Clegg, S., Dennis-Smither, B., Hallquist, M., Hallquist, A. M., Khlystov, A., Kulmala, M., Mogensen, D., Percival, C. J., Pope, F., Reid, J. P., Ribeiroda Silva, M. A. V., Rosenoern, T., Salo, K., Soonsin, V. P., Yli-Juuti, T., Prisle, N. L., Pagels, J., Rarey, J., Zardini, A. A., and Riipinen, T.: Saturation vapor pressures and transition enthalpies of low-volatility organic molecules of atmospheric relevance: from dicardoxylic acids to complex mixtures, Chem. Rev., 115, 41154156, doi:10.1021/cr5005502, 2015.

Brandner, J. D., Junk, N. M., Lawrence, J. W., and Robins, J.: Vapor Pressure of Ammonium Nitrate, J. Chem. Eng. Data, 7, 227-228, 1962.

Canagaratna, M. R., Jayne, J. T., Jimenez, J. L., Allan, J. D., Alfarra, M. R., Zhang, Q., Onasch, T. B., Drewnick, F., Coe, H., Middlebrook, A., Delia, A., Williams, L. R., Trimborn, A. M., Northway, M. J., DeCarlo, P. F., Kolb, C. E., Davidovits, P., and Worsnop, D. R.: Chemical and Microphysical Characterization of Ambient Aerosols with the Aerodyne Aerosol Mass Spectrometer, Mass Spectrom. Rev., 26, 185-222, doi:10.1002/mas.20115, 2007.

Canonaco, F., Crippa, M., Slowik, J. G., Baltensperger, U., and Prévôt, A. S. H.: SoFi, an IGOR-based interface for the efficient use of the generalized multilinear engine (ME-2) for the source apportionment: ME-2 application to aerosol mass spectrometer data, Atmos. Meas. Tech., 6, 3649-3661, doi:10.5194/amt6-3649-2013, 2013.

Cappa, C. D. and Jimenez, J. L.: Quantitative estimates of the volatility of ambient organic aerosol, Atmos. Chem. Phys., 10, 5409-5424, doi:10.5194/acp-10-5409-2010, 2010.

Cappa, C. D. and Wilson, K. R.: Evolution of organic aerosol mass spectra upon heating: implications for OA phase and partitioning behavior, Atmos. Chem. Phys., 11, 1895-1911, doi:10.5194/acp11-1895-2011, 2011.
Chien, W. M., Chandra, D., Lau, K. H., Hildenbrand, D. L., and Helmy, A. M.: The vaporization of NH4NO3, J. Chem. Thermodyn., 42, 846-851, doi:10.1016/j.jct.2010.01.012, 2010.

DeCarlo, P. F., Kimmel, J. R., Trimborn, A., Northway, M. J., Jayne, J. T., Aiken, A. C., Gonin, M., Fuhrer, K., Horvath, T., Docherty, K., Worsnop, D. R., and Jimenez, J. L.: Field-Deployable, HighResolution, Time-of-Flight Aerosol Mass Spectrometer, Anal. Chem., 78, 8281-8289, doi:10.1021/ac061249n, 2006.

Donahue, N. M., Robinson, A. L., Stanier, C. O., and Pandis, S. N.: Coupled Partitioning, dilution, and chemical aging of semivolatile organics, Environ. Sci. Technol., 40, 2635-2643, doi:10.1021/es052297c, 2006.

Donahue, N. M., Ortega, I. K., Chuang, W., Riipinen, I., Riccobono, F., Schobesberger, S., Dommen, J., Baltensperger, U., Kulmala, M., Worsnop, D. R., and Vehkamaki, H.: How do organic vapors contribute to new-particle formation?, Faraday Discuss., 165, 91-104, 2013.

Ehn, M., Petäjä, T., Birmili, W., Junninen, H., Aalto, P., and Kulmala, M.: Non-volatile residuals of newly formed atmospheric particles in the boreal forest, Atmos. Chem. Phys., 7, 677-684, doi:10.5194/acp-7-677-2007, 2007.

Ehn, M., Thornton, J. A., Kleist, E., Sipilä, M., Junninen, H., Pullinen, I., Springer, M., Rubach, F., Tillmann, R., Lee, B., LopezHilfiker, F., Andres, S., Acir, I.-H., Rissanen, M., Jokinen, T., Schobesberger, S., Kangasluoma, J., Kontkanen, J., Nieminen, T., Kurten, T., Nielsen , L. B., Jørgensen, S., Kjaergaard, H. G., Canagaratna, M., Dal Maso, M., Berndt, T., Petäjä, T., Wahner, A., Kerminen, V.-M., Kulmala, M., Worsnop, D. R., Wildt, J., and Mentel, T. F.: A large source of low-volatility secondary organic aerosol, Nature, 506, 476-479, doi:10.1038/nature13032, 2014.

Epstein, S. A., Riipinen, I., and Donahue, N. M.: A Semiempirical Correlation between Enthalpy of Vaporization and Saturation Concentration for Organic Aerosol, Environ. Sci. Technol., 44, 743-748, doi:10.1021/es902497z, 2010.

Goldstein, A. H. and Galbally, I. E.: Known and unexplored organic constituents in the earth's atmosphere, Environ. Sci. Technol., 41, 1514-1521, doi:10.1021/es072476p, 2007.

Gysel, M., Crosier, J., Topping, D. O., Whitehead, J. D., Bower, K. N., Cubison, M. J., Williams, P. I., Flynn, M. J., McFiggans, G. B., and Coe, H.: Closure study between chemical composition and hygroscopic growth of aerosol particles during TORCH2, Atmos. Chem. Phys., 7, 6131-6144, doi:10.5194/acp-7-61312007, 2007.

Gysel, M., McFiggans, G. B., and Coe, H.: Inversion of tandem differential mobility analyser (TDMA) measurements, J. Aerosol. Sci., 40, 134-151, 2009.

Hallquist, M., Wenger, J. C., Baltensperger, U., Rudich, Y., Simpson, D., Claeys, M., Dommen, J., Donahue, N. M., George, C., Goldstein, A. H., Hamilton, J. F., Herrmann, H., Hoffmann, T., Iinuma, Y., Jang, M., Jenkin, M. E., Jimenez, J. L., Kiendler-Scharr, A., Maenhaut, W., McFiggans, G., Mentel, Th. F., Monod, A., Prévôt, A. S. H., Seinfeld, J. H., Surratt, J. D., Szmigielski, R., and Wildt, J.: The formation, properties and impact of secondary organic aerosol: current and emerging issues, Atmos. Chem. Phys., 9, 5155-5236, doi:10.5194/acp-9-51552009, 2009.

Häkkinen, S. A. K., Äijälä, M., Lehtipalo, K., Junninen, H., Backman, J., Virkkula, A., Nieminen, T., Vestenius, M., Hakola, H., 
Ehn, M., Worsnop, D. R., Kulmala, M., Petäjä, T., and Riipinen, I.: Long-term volatility measurements of submicron atmospheric aerosol in Hyytiälä, Finland, Atmos. Chem. Phys., 12, 1077110786, doi:10.5194/acp-12-10771-2012, 2012.

Häkkinen, S. A. K., McNeill, V. F., and Riipinen, I.: Effect of inorganic salts on the volatility of organic acids, Environ. Sci. Technol., 48, 13718-13726, doi:10.1021/es5033103, 2014.

Hari, P. and Kulmala, M.: Station for Measuring EcosystemAtmosphere Relations (SMEAR II), Boreal Env. Res., 10, 315322,2005 .

Hildebrandt, L., Engelhart, G. J., Mohr, C., Kostenidou, E., Lanz, V. A., Bougiatioti, A., DeCarlo, P. F., Prevot, A. S. H., Baltensperger, U., Mihalopoulos, N., Donahue, N. M., and Pandis, S. N.: Aged organic aerosol in the Eastern Mediterranean: the Finokalia Aerosol Measurement Experiment - 2008, Atmos. Chem. Phys., 10, 4167-4186, doi:10.5194/acp-10-4167-2010, 2010.

Hildenbrand, D. L., Lau, K. H., and Chandra, D.: Thermochemistry of gaseous ammonium nitrate, NH4NO3(g), J. Phys. Chem. B, 114, 330-332, doi:10.1021/jp908062d, 2010a.

Hildenbrand, D. L., Lau, K. H., and Chandra, D.: Revised thermochemistry of gaseous ammonium nitrate, NH4NO3(g), J. Phys. Chem. A, 114, 11654-11655, doi:10.1021/jp105773q, 2010 b.

Hong, J., Häkkinen, S. A. K., Paramonov, M., Äijälä, M., Hakala, J., Nieminen, T., Mikkilä, J., Prisle, N. L., Kulmala, M., Riipinen, I., Bilde, M., Kerminen, V.-M., and Petäjä, T.: Hygroscopicity, $\mathrm{CCN}$ and volatility properties of submicron atmospheric aerosol in a boreal forest environment during the summer of 2010, Atmos. Chem. Phys., 14, 4733-4748, doi:10.5194/acp-144733-2014, 2014.

Huffman, J. A., Docherty, K. S., Aiken, A. C., Cubison, M. J., U1brich, I. M., DeCarlo, P. F., Sueper, D., Jayne, J. T., Worsnop, D. R., Ziemann, P. J., and Jimenez, J. L.: Chemically-resolved aerosol volatility measurements from two megacity field studies, Atmos. Chem. Phys., 9, 7161-7182, doi:10.5194/acp-9-71612009, 2009.

IPCC 2013: Climate change 2013: the physical science basis, Working Group I Contribution to the Fifth Assessment Report of the Intergovernmental Panel on Climate Change, Cambridge University Press, Cambridge, United Kingdom and New York, NY, USA, 2013.

Jimenez, J. L., Canagaratna, M. R., Donahue, N. M., Prevot, A. S. H., Zhang, Q., Kroll, J. H., DeCarlo, P. F., Allan, J. D., Coe, H., Ng, N. L., Aiken, A. C., Docherty, K. S., Ulbrich, I. M., Grieshop, A. P., Robinson, A. L., Duplissy, J., Smith, J. D., Wilson, K. R., Lanz, V. A., Hueglin, C., Sun, Y. L., Tian, J., Laaksonen, A., Raatikainen, T., Rautiainen, J., Vaattovaara, P., Ehn, M., Kulnala, M., Tomlinson, J. M., Collins, D. R., Cubison, M. J., Dunlea, E. J., Huffman, J. A., Onasch, T. B., Alfarra, M. R., Williams, P. I., Bower, K., Kondo, Y., Schneider, J., Drewnick, F., Borrmann, S., Weimer, S., Demerjian, K., Salcedo, D., Cottrell, L., Griffin, R., Takami, A., Miyoshi, T., Hatakeyama, S., Shimono, A., Sun, J. Y., Zhang, Y. M., Dzepina, K., Kimmel, J. R., Sueper, D., Jayne, J. T., Herndon, S. C., Trimborn, A. M., Williams, L. R., Wood, E. C., Middlebrook, A. M., Kolb, C. E., Baltensperger, U., and Worsnop, D. R.: Evolution of organic aerosols in the atmosphere, Science, 326, 1525, doi:10.1126/science.1180353, 2009.
Kanakidou, M., Seinfeld, J. H., Pandis, S. N., Barnes, I., Dentener, F. J., Facchini, M. C., Van Dingenen, R., Ervens, B., Nenes, A., Nielsen, C. J., Swietlicki, E., Putaud, J. P., Balkanski, Y., Fuzzi, S., Horth, J., Moortgat, G. K., Winterhalter, R., Myhre, C. E. L., Tsigaridis, K., Vignati, E., Stephanou, E. G., and Wilson, J.: Organic aerosol and global climate modelling: a review, Atmos. Chem. Phys., 5, 1053-1123, doi:10.5194/acp-5-1053-2005, 2005.

Kreidenweis, S. M., McInnes, L. M., and Brechtel, F. J.: Observations of aerosol volatility and elemental composition at Macquarie Island during the First Aerosol Characterization Experiment (ACE 1), J. Geophys. Res.-Atmos., 103, 16511-16524, 1998.

Kroll, J. H., Donahue, N. M., Jimenez, J. L., Kessler, S. H., Canagaratna, M. R., Wilson, K. R., Altieri, K. E., Mazzoleni, L. R., Wozniak, A. S., Bluhm, H., Mysak, E. R., Smith, J. D., Kolb, C. E., and Worsnop, D. R.: Carbon oxidation state as a metric for describing the chemistry of atmospheric organic aerosol, Nat. Chem., 3, 133, doi:10.1038/NCHEM.948, 2011.

Lanz, V. A., Alfarra, M. R., Baltensperger, U., Buchmann, B., Hueglin, C., and Prévôt, A. S. H.: Source apportionment of submicron organic aerosols at an urban site by factor analytical modelling of aerosol mass spectra, Atmos. Chem. Phys., 7, 15031522, doi:10.5194/acp-7-1503-2007, 2007.

Lee, B. H., Kostenidou, E., Hildebrandt, L., Riipinen, I., Engelhart, G. J., Mohr, C., DeCarlo, P. F., Mihalopoulos, N., Prevot, A. S. H., Baltensperger, U., and Pandis, S. N.: Measurement of the ambient organic aerosol volatility distribution: application during the Finokalia Aerosol Measurement Experiment (FAME2008), Atmos. Chem. Phys., 10, 12149-12160, doi:10.5194/acp10-12149-2010, 2010.

Murphy, B. N., Donahue, N. M., Robinson, A. L., and Pandis, S. N.: A naming convention for atmospheric organic aerosol, Atmos. Chem. Phys., 14, 5825-5839, doi:10.5194/acp-14-58252014, 2014.

Ng, N. L., Canagaratna, M. R., Zhang, Q., Jimenez, J. L., Tian, J., Ulbrich, I. M., Kroll, J. H., Docherty, K. S., Chhabra, P. S., Bahreini, R., Murphy, S. M., Seinfeld, J. H., Hildebrandt, L., Donahue, N. M., DeCarlo, P. F., Lanz, V. A., Prévôt, A. S. H., Dinar, E., Rudich, Y., and Worsnop, D. R.: Organic aerosol components observed in Northern Hemispheric datasets from Aerosol Mass Spectrometry, Atmos. Chem. Phys., 10, 46254641, doi:10.5194/acp-10-4625-2010, 2010.

Offenberg, J. H., Kleindienst, T. E., Jaoui, M., Lewandowski, M., and Edney, E. O.: Thermal properties of secondary organic aerosols, Geophys. Res. Lett., 33, L03816, doi:10.1029/2005GL024623, 2006.

Paatero, P.: Least squares formulation of robust non-negative factor analysis, Chemometr. Intell. Lab., 37, 23-35, 1997.

Paciga, A., Karnezi, E., Kostenidou, E., Hildebrandt, L., Psichoudaki, M., Engelhart, G. J., Lee, B.-H., Crippa, M., Prévôt, A. S. H., Baltensperger, U., and Pandis, S. N.: Volatility of organic aerosol and its components in the megacity of Paris, Atmos. Chem. Phys., 16, 2013-2023, doi:10.5194/acp-16-20132016, 2016.

Pankow, J. F.: An Absorption-Model of Gas-Particle Partitioning of Organic-Compounds in the Atmosphere, Atmos. Environ., 28 , 185-188, 1994. 
Reilly, P. J. and Wood, R. H.: Prediction of properties of mixed electrolytes from measurements on common ion mixtures, J. Phys. Chem., 73, 4292-4297, 1969.

Riipinen, I., Pierce, J. R., Donahue, N. M., and Pandis, S. N.: Equilibration time scales of organic aerosol inside thermodenuders: Evaporation kinetics versus thermodynamics, Atmos. Environ., 44, 597-607, 2010.

Saleh, R., Donahue, N. M., and Robinson, A. L.: Time scales for gas-particle partitioning equilibration of secondary organic aerosol formed from alpha-pinene ozonolysis, Environ. Sci. Technol., 47, 5588-5594, doi:10.1021/es400078d, 2013.

Salo, K., Westerlund, J., Andersson, P. U., Nielsen, C., D’Anna, B., and Hallquist, M.: Thermal characterization of aminium nitrate nanoparticles, J. Phys. Chem. A, 115, 11671-11677, doi:10.1021/jp204957k, 2011.

Tong, H.-J., Reid, J. P., Bones, D. L., Luo, B. P., and Krieger, U. K.: Measurements of the timescales for the mass transfer of water in glassy aerosol at low relative humidity and ambient temperature, Atmos. Chem. Phys., 11, 4739-4754, doi:10.5194/acp-11-47392011, 2011.

Ulbrich, I. M., Canagaratna, M. R., Zhang, Q., Worsnop, D. R., and Jimenez, J. L.: Interpretation of organic components from Positive Matrix Factorization of aerosol mass spectrometric data, Atmos. Chem. Phys., 9, 2891-2918, doi:10.5194/acp-9-2891-2009, 2009.
Vallina, P., Picard, D., Marchand, N., and Laj, P.: Design and validation of a 6-volatility tandem differential mobility analyzer (VTDMA), Aerosol Sci. Tech., 41, 898-906, doi:10.1080/02786820701534593, 2007.

Virtanen, A., Joutsensaari, J., Koop, T., Kannosto, J., Yli-Pirilä, P., Leskinen, J., Mäkelä, J. M., Holopainen, J. K., Pöschl, U., Kulmala, M., Worsnop, D. R., and Laaksonen, A.: An amorphous solid state of biogenic secondary organic aerosol particles, Nature, 467, 824-827, doi:10.1038/nature09455, 2010.

Wehner, B., Philippin, S., and Wiedensohler, A.: Design and calibration of a thermodenuder with an improved heating unit to measure the size-dependent volatile fraction of aerosol particles, J. Aerosol Sci., 33, 1087-1093, 2002.

Winklmayr, W., Reischl, G. P., Lindner, A. O., and Berner, A.: A new electromobility spectrometer for the measurement of aerosol size distributions in the size range from 1 to $1000 \mathrm{~nm}$, J. Aerosol Sci., 22, 289-296, doi:10.1016/S0021-8502(05)80007-2, 1991.

Zhang, Q., Jimenez, J., Canagaratna, M., Ulbrich, I., Ng, N., Worsnop, D., and Sun, Y.: Understanding atmospheric organic aerosols via factor analysis of aerosol mass spectrometry: a review, Anal. Bioanal. Chem., 401, 3045-3067, 2011. 